\title{
Financial Attractiveness and Operating Characteristics of E-Rickshaw in Bangladesh: A Case Study
}

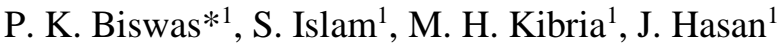 \\ Department of Industrial and Production Engineering, \\ Shahjalal University of Science and Technology ${ }^{1}$
}

\author{
S. $\operatorname{Das}^{2}$ \\ Department of Mechanical Engineering, \\ Rajshahi University of Engineering \& Technology ${ }^{2}$
}

\author{
S. R. Sourov ${ }^{3}$ \\ Department of Textile Engineering, \\ National Institute of Textile Engineering \& Research ${ }^{3}$
}

\begin{abstract}
Global transportation trend is going a major transformation from fossil fuel based to electric vehicles (EVs). Bangladesh, being on the enormous progressive pathway to be recognized as a developing country by 2024 , is not an exception to this transformation. E-rickshaw is the only known form of EVs currently used as a public road transportation system in Bangladesh. This study contains primary data based analysis on the financial attractiveness of e-rickshaw from investor's point of view. Several related issues such as run time after full charging, energy consumption level at different age of battery are also explored. The finding shows that investment in this mode of transportation is highly profitable with a profit investment ratio of 1.96. Depreciation has an effect on the profitability difference between rented and owned e-rickshaw. Finding also reveals that e-rickshaw battery consumes 4.61 kilowatt-hour electric energy per full charging and runs 9.73 hours. However, with increasing battery life battery efficiency decreases significantly.
\end{abstract}

Keywords-E-rickshaw, Electric vehicle, Investment attractiveness, Energy consumption.

\section{INTRODUCTION}

World transport landscape is undergoing a major transformation. Electricity and low carbon fuels, for instance, natural gas and biofuels are steadily replacing conventional fuels and technologies. The transport sector, which is one of the largest energy consuming sectors, is overly dependent on liquid fossil fuels. This high volume burning of fossil fuels is responsible for harmful emission, global warming, climate change, energy insecurity, and unbreathable air condition. Globally, researchers are trying to develop promising technological innovation that has the potential to reduce the problems generated from fossil fuel burning. Use of low carbon fuels could be a solution but its sources are limited. Electric Vehicles (EVs) are one such option to alleviate this problem since it offers the lowest emissions intensity [1-2]. EVs also has the potential to improve energy efficiency and there is a continuous search for improved battery technologies that will bring down costs and increase energy density [3]. Globally, policymakers and automobile manufacturers are now concerned about EVs and its future prospects. Several contemporary studies identified a few factors that influences EVs market share significantly include high battery costs, financial incentives, charging infrastructure, and local production [4-5]. The global EVs market is anticipated to escalate significantly in the near future. The number of EVs is estimated to become triple from current levels by 2020 [1]. The financial benefit of EV buyers and low carbon were found most influential factors behind the rapid increase of this mode [6].

Several studies showed that battery operated e-rickshaws do not produce any air pollution. Mader and TEC in their study showed that about $35-50 \%$ emission of nitric oxide and reactive organic gases, $45-65 \%$ usage of petroleum and 30 $45 \%$ emission of greenhouse gases in city areas can be reduced by substituting the diesel and petroleum operated vehicles with battery operated eclectic vehicles [7] Following this advantage, to curb air pollution in the Kathmandu valley of Nepal, the government encourage the use of battery operated e-rickshaw in lieu of diesel operated three-wheelers [8]. In Bangladesh, battery operated electric rickshaw (e-rickshaw), commonly called auto, is the only prominent form of EV currently being used in public road transportation system. The mode is lightweight and runs at limited speed, faster than the traditional human pulled rickshaw, therefore it does not produce fatal accidents [9]. This mode is generally used for traveling short distances. Rana et al. showed that $85 \%$ of e-rickshaw trips range less than 5 kilometers [10]. Being introduced newly, this mode is also generating employment in Bangladesh [11]. However, no large investment in e-rickshaw by any financial institutions and organizations is observed except personal level. Which raises the question of profitability on investment in this form of transportation mode. Power consumption and run time per full charge also directly affect the operating performance of e-rickshaw. Hence, to attract large investors, proper financial evaluation of e-rickshaw in Bangladesh is of great importance. Besides, a systematic study estimating power consumption and run time at different age of the battery is lacking. This article, therefore, focuses on:

- Evaluate the financial attractiveness of e-rickshaw of being a profitable investment choice.

- Energy consumption and run time of e-rickshaw and its variation along different battery ages. 


\section{MATERIAL AND METHODS}

Profit investment ratio is also known as profitability index is a measure of profitability. Profitability is simply the ability to make a profit, and a profit is what is left over from revenue earned after deducting all costs and expenses related to earning the revenue. Any negative value indicates that the project's profit is less than the investment while any positive value indicates a profit. As the value of the profit investment ratio increases, so does the financial attractiveness of the proposed project [12]. In this study, profit investment ratio is used to evaluate the financial attractiveness of investment in e-rickshaw. The ratio is calculated as follows:

Profit investment ratio $(\mathrm{PIR})=\frac{\text { Revenue-Investment }}{\text { Investment }}$

An electronic watt-hour meter commonly known as energy meter or electricity meter is a device that measures the quantity of electric energy consumed by an electrically powered device [13]. The electricity meter generally measures the consumed electric energy in the kilowatt-hour $(\mathrm{kWh})$ unit, since this unit is most commonly used for billing purpose and known widely. In this study, digital electricity meter was used for measuring energy consumption per full charging of the e-rickshaw battery. The electricity meter was tested and calibrated each time before taking data.

\section{ANALYSIS AND DISCUSSION}

A total of 60 electric rickshaw battery, each five times, charging data has been recorded. This data of e-rickshaw battery comprises of 30 batteries which age is less than three months and rest 30 batteries whose age is between three to six months. The collected data include the nominal capacity of the battery, supply voltage, number of cell in the battery bank, battery age, run time, and energy consumption for full charging. Total run time after each full charges was also recorded.

Table I shows the collected data and obtained information about energy consumption per full charging, and run time after full charging at different age of the e-rickshaw battery. The nominal capacity of all the batteries was 60 amperehour and the output voltage was 60 volts which comprise 5 cells in a battery pack. Depending on the supply voltage,

TABLE I. OPERATING CHARACTERISTICS OF E-RICKSHAW

\begin{tabular}{|c|c|c|c|c|c|}
\hline \multicolumn{3}{|c|}{ Less than three months old battery } & \multicolumn{3}{|c|}{ Between three to six months old battery } \\
\hline Battery Age (days) & $\begin{array}{l}\text { Run Time } \\
\text { (Minutes) }\end{array}$ & $\begin{array}{l}\text { Energy Consumption } \\
\text { per charging }(\mathrm{kWh})\end{array}$ & Battery Age (days) & $\begin{array}{l}\text { Run Time } \\
\text { (Minutes) }\end{array}$ & $\begin{array}{l}\text { Energy Consumption } \\
\text { per charging }(\mathrm{kWh})\end{array}$ \\
\hline 5 & 609 & 3.92 & 106 & 471 & 6.34 \\
\hline 9 & 612 & 4.01 & 109 & 476 & 6.47 \\
\hline 10 & 598 & 4.17 & 110 & 454 & 6.37 \\
\hline 14 & 608 & 3.97 & 124 & 469 & 6.63 \\
\hline 21 & 605 & 3.93 & 126 & 426 & 6.50 \\
\hline 25 & 603 & 4.04 & 127 & 462 & 6.73 \\
\hline 26 & 602 & 4.07 & 136 & 461 & 7.16 \\
\hline 27 & 608 & 3.96 & 136 & 469 & 6.83 \\
\hline 29 & 596 & 4.26 & 137 & 452 & 7.92 \\
\hline 36 & 607 & 4.33 & 139 & 468 & 7.89 \\
\hline 37 & 594 & 4.59 & 139 & 437 & 7.69 \\
\hline 38 & 585 & 4.39 & 168 & 435 & 7.69 \\
\hline 40 & 592 & 4.97 & 173 & 445 & 7.46 \\
\hline 41 & 583 & 4.51 & 179 & 432 & 9.41 \\
\hline 45 & 582 & 4.54 & 207 & 430 & 8.55 \\
\hline 45 & 580 & 4.72 & 220 & 428 & 10.03 \\
\hline 47 & 584 & 4.33 & 255 & 434 & 8.38 \\
\hline 48 & 576 & 4.66 & 280 & 422 & 11.55 \\
\hline 50 & 574 & 4.54 & 293 & 418 & 8.98 \\
\hline 51 & 569 & 4.85 & 300 & 411 & 10.59 \\
\hline 53 & 570 & 4.97 & 300 & 413 & 9.80 \\
\hline 53 & 573 & 4.40 & 314 & 417 & 9.80 \\
\hline 58 & 562 & 5.03 & 322 & 401 & 10.00 \\
\hline 61 & 567 & 5.04 & 336 & 408 & 8.38 \\
\hline 72 & 567 & 5.21 & 339 & 408 & 10.16 \\
\hline 76 & 555 & 5.19 & 341 & 390 & 10.53 \\
\hline 78 & 569 & 5.08 & 342 & 411 & 12.87 \\
\hline 79 & 561 & 5.26 & 343 & 399 & 10.76 \\
\hline 79 & 555 & 5.90 & 345 & 390 & 8.78 \\
\hline 85 & 564 & 5.50 & 352 & 403 & 8.90 \\
\hline Average & 584 & 4.61 & Average & 431 & 8.64 \\
\hline
\end{tabular}


power factor, battery age, and charging time, energy consumption per full charging varies from 3.92 kilowatthours to 5.90 kilowatt-hours and run time after full charging varies from 9.25 hours to 10.20 hours.

So, on an average e-rickshaw battery consumes 4.61 kilowatt-hours energy and with this energy run 9.73 hours when battery age was below three months. With the increase of battery age energy consumption increases while run time decreases. When the battery age ranges between three to six months, energy consumption per charging varies from 6.34 kilowatt-hours to 12.87 kilowatt-hours and run time after full charging varies from 6.50 hours to 7.93 hours. On
Table II shows the starting and end point of each five routes along with distances between them. From each route, 60 data has been taken of which 30 was operated by the owner itself and the rest 30 was operated by renting from the owner. Investment in e-rickshaw is the amount of money that was spent on purchasing and keeping the vehicle in operating condition. Currently, the government has to policy on erickshaw registration of e-rickshaw. E-rickshaw owners generally got a license and road permit from the local association by a small amount of fees.

If the vehicle is owned by the operator then the investment

TABLE III. E-RICKSHAW FICANCIAL CHARACTERISTICS

\begin{tabular}{|c|c|c|c|c|c|c|}
\hline & \multicolumn{3}{|c|}{ Ownership status: Owned } & \multicolumn{3}{c|}{ Ownership status: Rented } \\
\hline Route & $\begin{array}{c}\text { Monthly } \\
\text { investment } \\
\text { (Avg.) BDT }\end{array}$ & $\begin{array}{c}\text { Monthly profit } \\
\text { (Avg.) BDT }\end{array}$ & $\begin{array}{c}\text { Profit } \\
\text { investment } \\
\text { ratio }\end{array}$ & $\begin{array}{c}\text { Monthly } \\
\text { investment } \\
\text { (Avg.) BDT }\end{array}$ & $\begin{array}{c}\text { Monthly profit } \\
\text { (Avg.) BDT }\end{array}$ & $\begin{array}{c}\text { Profit } \\
\text { investment ratio }\end{array}$ \\
\hline Route 1 & $9,700.00$ & $16,684.00$ & 1.72 & $7,930.00$ & $17,755.00$ & 2.24 \\
\hline Route 2 & $10,050.00$ & $18,592.00$ & 1.85 & $8,427.00$ & $17,950.00$ & 2.13 \\
\hline Route 3 & $9,350.00$ & $18,420.00$ & 1.97 & $8,860.00$ & $19,048.00$ & 2.15 \\
\hline Route 4 & $10,000.00$ & $16,800.00$ & 1.68 & $7,934.00$ & $16,740.00$ & 2.11 \\
\hline Route 5 & $9,800.00$ & $18,424.00$ & 1.88 & $8,930.00$ & $18,575.00$ & 2.08 \\
\hline Average & $9,780.00$ & $17,784.00$ & 1.82 & $8,416.00$ & $18,014.00$ & 2.14 \\
\hline Overall & $9,098.00$ & $17,899.00$ & 1.96 & & &
\end{tabular}

average, the battery of e-rickshaw battery consumes 8.64 kilowatt-hour electric energy and runs 7.18 hours when battery age is between three to six months.

To measure the degree and direction of the relationship between battery age and run time, correlation analysis has been performed using IBM SPSS Statistics V21. Pearson correlation coefficient between battery age and run time was found $r=-0.916$, which indicate a strong negative relationship between them. With the increased battery life, e-rickshaw battery run time decreases very rapidly in a linear manner. In order to get optimal performance from erickshaw, the battery should be replaced after one year. is usually its assembling cost, charging cost, maintenance cost, and parts replacement cost. The assembling cost is expressed as monthly depreciation. If the vehicle was rented by the operator from the owner then the investment is the amount of money the operator pays as rent to the owner per day and maintenance cost (usually very less amount). When the operator rents the e-rickshaw from the owner, he has to pay rent on a daily basis which varies from 180 BDT to 250 BDT. Operator received the fully charged e-rickshaw from the owner and return to him when charge finished. The operator does not have to pay the charging costs, large maintenance costs, and parts replacement costs, only pay

TABLE II. ROUTE CHARACTERISTICS OF JESSORE CITY

\begin{tabular}{|c|c|c|c|c|c|}
\hline & & & & Number of e-1 & wnership status \\
\hline Route & Starting point & End point & Distance & Rented & owned \\
\hline Route 1 & New Market Bus Stand & Monihar Bus Stop & $2.4 \mathrm{~km}$ & 30 & 30 \\
\hline Route 2 & New Market Bus Stand & Palbari Mor Bus Stop & $2.2 \mathrm{~km}$ & 30 & 30 \\
\hline Route 3 & New Market Bus Stand & Daratana & $1.5 \mathrm{~km}$ & 30 & 30 \\
\hline Route 4 & Daratana & Arabpur Bus Stop & $1.8 \mathrm{~km}$ & 30 & 30 \\
\hline Route 5 & Daratana & Jessore Railway Junction & $1.6 \mathrm{~km}$ & 30 & 30 \\
\hline
\end{tabular}

To measure the financial attractiveness of investment in erickshaw, profit investment ratio is used in this study. Jessore city, the largest city of Khulna District in Bangladesh, was selected for data collection as the whole city commuter depends heavily on e-rickshaw for their daily transportation. The e-rickshaw operates in five routes of this city. To equalize any difference, the same number of erickshaw data was collected from each route at the same time span of a day. insignificant repair and maintenance costs. Revenue is the amount of money the operator gets from passengers by serving them to deliver at desired destination. The profit is calculated by subtracting investment from revenue. The profit investment ratio is calculated by dividing the amount of profit by the amount of investment. The data was presented on a monthly basis.

Table III shows the profit investment ratios of e-rickshaw on each of the five routes. On average the profit investment ratio of owned e-rickshaw was found 1.82 while rented erickshaw was found 2.14 . The profit investment ratio was 
found higher for rented e-rickshaw than owned e-rickshaw in all routes, although the differences were insignificant. Overall, e-rickshaw was found a very attractive investment alternative as it encompasses a profit investment ratio of 1.96.

To further investigate the cause of the higher profit investment ratio of rented e-rickshaw than owned erickshaw, depreciation of owned e-rickshaw was calculated. Depreciation is a useful accounting technique of allocating

TABLE IV. DEPRECIATION OF E-RICKSHAW

\begin{tabular}{|l|r|}
\hline Price of new e-rickshaw (Avg.) & $2,20,000.00$ BDT \\
\hline Economic service life (Avg.) & 3 year \\
\hline Battery replacement after each one year & $60,000.00$ BDT \\
\hline Salvage value (Avg.) & $25,000.00$ BDT \\
\hline Depreciable amount & $2,55,000.00$ BDT \\
\hline Depreciation (Monthly) & 7083.00 BDT \\
\hline
\end{tabular}

the cost of a tangible asset over its economic service life and is used to account for declines in value. In this study, it can be viewed as a cost of the e-rickshaw owner.

Table IV shows the monthly depreciation of e-rickshaw. This result is obtained using the straight-line depreciation method. Due to short economic service life and replacement of battery pack after each year, e-rickshaw generates a high amount of monthly depreciation near the owner. This is the reason behind the higher profit investment ratio of rented erickshaw. On average e-rickshaw operator makes a monthly profit of 17,784 BDT when they owned the vehicle and 18,014 BDT when they rented the vehicle from the owner. In both situations, investment in e-rickshaw is financially beneficial.

\section{CONCLUSION}

Electric vehicles (EVs) is the future of transportation technology. In Bangladesh, e-rickshaws are already rolling on the streets and gains public attention. Investing in this mode was found highly profitable with a profit investment ration of 1.96. E-rickshaw battery efficiency decreases rapidly with increasing age. Better battery technology and solar battery hybrid could be a game changer for this mode. Finally, the extensive uptake and adoption of e-rickshaw depend on global and local technological innovations, cognizance of citizens and support from national and local governments.

\section{REFERENCES}

[1] Shukla, P. R., Dhar, S., Pathak, M., \& Bhaskar, K. (2014). Electric vehicle scenarios and a roadmap for India. PROMOTING LOW CARBON TRANSPORT IN INDIA, UNEP DTU Partnership, Centre on Energy, Climate and Sustainable Development Technical University of Denmark.

[2] Nanaki, E. A., \& Koroneos, C. J. (2013). Comparative economic and environmental analysis of conventional, hybrid and electric vehicles-the case study of Greece. Journal of cleaner production, 53, 261-266.

[3] Yagcitekin, B., Uzunoglu, M., Karakas, A., \& Erdinc, O. (2015). Assessment of electrically-driven vehicles in terms of emission impacts and energy requirements: a case study for Istanbul, Turkey. Journal of Cleaner Production, 96, 486-492.

[4] Wu, Z., Ma, Q., \& Li, C. (2015). Performance investigation and analysis of market-oriented low-speed electric vehicles in China. Journal of Cleaner Production, 91, 305-312.

[5] Sierzchula, W., Bakker, S., Maat, K., \& Van Wee, B. (2014). The influence of financial incentives and other socio-economic factors on electric vehicle adoption. Energy Policy, 68, 183-194.

[6] Dhar, S., Pathak, M., \& Shukla, P. R. (2017). Electric vehicles and India's low carbon passenger transport: a long-term co-benefits assessment. Journal of cleaner production, 146, 139-148.

[7] Mader, J., \& TEC, T. E. C. (2006). Battery Powered Vehicles: Don't rule them out. Transportation Energy Center, University of Michigan, November, 16, 4

[8] Dhakal, D. S. (2005). Role of Government, private sector and civic society in promoting battery operated electric three-wheelers in Kathmandu, Nepal. Institute for Global Environmental Strategies (IGES), Kitakyushu Office, 19.

[9] Mohan, D. D. (2007). Three-wheeled scooter taxi: Problems and solutions for an efficient mode of transport. Institute of Urban Transport, New Delhi$110011,11$.

[10] Rana, M. S., Hossain, F., Roy, S. S., \& Mitra, M. S. K. (2013). Exploring operational characteristics of battery operated auto-rickshaws in urban transportation system. American Journal of Engineering Research, 2(4), 01 11

[11] Rana, S., Hossain, F., Roy, S. S., \& Mitra, S. K. (2013). The role of battery operated auto-rickshaw in the transportation system of a city. Journal of Asian Electric Vehicles, 11(1), 1635-1644.

[12] Baldacci, E., Hillman, A. L., \& Kojo, N. C. (2004). Growth, governance, and fiscal policy transmission channels in low-income countries. European Journal of Political Economy, 20(3), 517-549.

[13] Landman, R. G., Spring, H. G., \& Burba, J. C. (1989). U.S. Patent No. 4,795,974. Washington, DC: U.S. Patent and Trademark Office. 